\title{
Construction Practice and Strategy Research on Top-Quality Online Open Courses in Colleges and Universities
}

\author{
Lijuan Wan ${ }^{1}$ and Ximei Liu ${ }^{2, *}$ \\ ${ }^{1}$ School of Mathematics and Physics, Qingdao University of Science and Technology, Qingdao, \\ Shandong, China, \\ ${ }^{2}$ College of Automation and Electronic Engineering, Qingdao University of Science and Technology, \\ Qingdao, Shandong, China \\ *Corresponding author
}

Keywords: Higher Mathematics; Online Open Course; Blended Teaching

\begin{abstract}
The construction of top-quality online open courses reflects the integration, sharing and development of network information technology and traditional teaching resources. It is an inevitable trend of teaching reform in the new era for constructing online open courses in the institutions of higher education. Based on the constructional experiences of "higher mathematics", this paper tends to summarize the contents and significance of the online open course construction, to analyze the advantages and disadvantages of the blended online and offline teaching mode and to put forward the strategies of constructing online open course, expecting to impact the educational wisdom and methods of online open course construction.
\end{abstract}

\section{Introduction}

With the development of computer network and the extension of information reformation, network teaching is normal now. Opening various network classes has become a mainstream trend of college teaching reform under the background of Internet technology and modern education information technology developing. In the past decade, the construction of MOOC, SPOC and other massive open online courses has become popular and spread worldwide. The characteristics of "large-scale", "strong openness", "free learning” and "resource sharing” represented by such courses are favored by education workers and various students. On April 2015, the document of the "The opinions of the ministry of education on strengthening the application and management of online open courses in colleges and universities" was released. Since then various colleges and universities have issued relevant policies, increased the technical construction of the online course platform of the school, and encouraged relevant teachers to apply for high-quality online course teaching and research projects. These measures will promote the extension of informatization reformation in teaching and constantly improve the teaching quality of undergraduates [1-2]. 


\section{Content and Form of Online Open Courses Construction}

The construction of fine online open courses is mainly reflected in the "integration" and "application" of course resources. A quality online open course construction, the work of the early stage mainly focuses on the sorting, teaching design and recording of micro-video. The teacher team fully takes into account the distribution of key and difficult points, the combination of theory and application and other requirements, and sorts out and subdivides the knowledge points according to the requirements of the course syllabus, Relevant teachers should design the content of the teaching section and make clear and beautiful teaching PPT according to the unified course template. Finally, the production of corresponding teaching video was completed with the help of professional recording staff, each teaching video teaches independent knowledge points, and the recording time is 10-15 minutes. In video, according to the progress of the explanation of knowledge points, the corresponding questions will pop up at the appropriate time points to promote students' thinking and grasp of key points. The course micro-video and related teaching materials are all online with the help of the Superstar and Pan-elegant Teaching platform. The course resources are set as self-learning area, discussion area, and notification area on the network platform. Students use their passwords to log on to the online open courses website. They can instantly access the teaching video, browse and download teaching materials, and conduct online learning, testing and discussion [3-4].

\section{The Purpose and Significance of Online Open Courses Construction}

\subsection{Realize the Informatization of Undergraduate Teaching and Promote the Coordinated Development of Network Information Technology and Education and Teaching Objectives}

In the era of Internet popularity, multimedia and online teaching have become the trend of global education development. The rise of MOOC and SPOC courses around the world has made us feel that the era of open educational activities and teaching management services based on network technology has arrived. With the emergence of various online open courses platforms in China, such as NetEase Open Course, Tsinghua University "School Online”, Superstar, and Wisdom Tree, the external conditions of online open courses construction have been guaranteed on the technical level. The introduction of the online open courses promotes the reform of the education model, effectively expands the types of students who are educated, increases the opportunities for students to learn from the curriculum, deepens their education, and realizes the full use of educational resources.

\subsection{Promote the Reform of the Teaching Model and Improve the Teaching Effect}

The construction of high-quality online open courses has realized the electronicization of paper teaching resources, promoted the deep integration of information technology and teaching content, and provided a feasible way for the implementation of flipping classroom. In the traditional classroom, students generally feel that the course content is lengthy, the learning intensity is large, the teaching form is single, and the interest in learning is not enough. However, in a network-covered campus, students can use the fragmented time to complete the learning of a course knowledge point and achieve time-optimized management. The vivid and interesting teaching videos can also greatly stimulate students' learning enthusiasm and improve learning efficiency. It promotes the transformation from "teacher-centered" to "student-centered" teaching model [5]. In the network teaching resources, students can choose independently, learn freely, communicate extensively with other students in the discussion area, and actively explore under the guidance and help of teachers, which is conducive to the realization of the curriculum objectives and the improvement of students' independent learning ability. 


\section{Advantages and Disadvantages in the Practice of Online Open Courses Construction in Colleges and Universities}

In view of the advantages and significance of the online open courses construction, the Academic Affairs Department of Qingdao University of Science and Technology vigorously develops an online open courses platform. The author is also fortunate to participate in the construction of the online open course of the school "Advanced Mathematics". Through nearly two years of efforts, this course has been successfully launched and put into use in the whole school. Under the guidance of the instructors, more than 2,000 science and engineering freshmen in the school successfully obtained the courses resources and achieved the goal of "building for use" of online open courses. The online open courses of higher mathematics also show obvious advantages and disadvantages in actual use. Next, this article will elaborate on this point from the online and offline aspects.

\subsection{Advantages in Online Course Performance}

\subsubsection{The Creation of Online Open Courses Reflects the Integration of High-quality Teaching Resources}

The significance of the construction of the boutique online open course is reflected in the integration of high-quality teaching resources and the realization of construction. The successful recording of a boutique online open course often embodies the strength of the entire teaching team. In terms of the selection and design of teaching contents, it also reflects the characteristics of "selection and perfection". On the explanation of key and difficult knowledge, the online open course strives to achieve the "three essences" standard of "refinement, accuracy and refinement. The teaching method and the teaching art are organically integrated together, striving to improve the quality of the course and increase the level of popularity.

\subsubsection{The Use of Online Open Courses Reflects the Advantages and Convenience of E-Learning Resources}

With the help of high-speed Internet, students can learn online without being limited by the time and place of learning and they can achieve independent free learning. In addition, online teaching video can be viewed repeatedly. Students can choose to watch the content of teaching video and the number of times according to their learning basis, so as to make a targeted learning plan for the course and timely understand and master the course knowledge. Moreover, by watching online course resources again, students can overcome learning forgetting, review and summarize more smoothly, deepen their understanding of course knowledge, and achieve active and efficient learning.

\subsection{Disadvantages of Offline Course Construction}

\subsubsection{The Effectiveness of Online Open Course Resources Needs to be Recognized and Promoted by More Frontline Teachers}

After the online open courses are put into use, teachers need to study the course content, grasp the course rhythm, integrate traditional classroom teaching with online courses systematically, and to arrange new teaching plans. Due to the use of online open courses, the change of the teaching mode brings great challenge to teachers. Even the online open courses, which have invested a lot of manpower and material resources, still face many difficulties in the actual use and promotion and it is urgent for more frontline teachers to change their teaching concepts, absorb new teaching methods and actively participate in the construction and use of online open courses 


\subsubsection{The Effectiveness of Open Online Course Resources Needs to Solve the Problem of Credit Mutual Recognition of Students' Online and Offline Learning}

The majority of students are always the subject of learning, and their acceptance of open online courses determines the main value of the course construction. However, through investigation, we find that there are some common problems in students' participation in the study of MOOCs. On the one hand, students' purpose of completing MOOCs is not clear. Generally speaking, students browse the page of online open courses and participate in the course learning only under the recommendation of course teachers. Due to the lack of systematic learning guidance, students' online learning often lacks sustainability. On the other hand, the lack of mature inspection standards and reasonable credit certification system for the learning effect of online courses makes it difficult for students to maintain their motivation for online learning and high rate of dropping courses [6].

\section{Strategies and Methods for the Construction of Online Open Courses in Colleges and Universities}

In view of the current status of online open curriculum construction, after conducting sufficient research and study, this paper proposes several practical online open curriculum construction strategies based on improving the use of online open courses.

\subsection{Optimize Curriculum Resources and Improve the Curriculum System Based on Professional Characteristics and Talent Training Objectives}

According to the current "Advanced Mathematics" online open course construction practice, as well as the author's many years of teaching experience, the significance of the construction of the online open course is reflected in the integration of high-quality teaching resources. In the designing and construction of online open courses for college mathematics, it is necessary to divide the course knowledge points into two modules: basic knowledge and professional application examples. Focus on adding relevant frontier research such as artificial intelligence and mathematics experiments in the application section, so as to help students to acquire the new knowledge and application and realize the new era education goal of cultivating students' comprehensive quality and innovative application ability.

\subsection{Actively Explore Online and Offline Hybrid Teaching Reform Methods, and Establish a New Model of Curriculum Teaching}

Since the online opening courses of Advanced Mathematics were launched, students have realized a new integrated teaching mode of "Online First Look - Classroom Explain - Online Consolidation Mixed Practice". In view of the different levels of curriculum teachers participating in the online open curriculum construction, they need to adjust the teaching plan in time, reasonably allocate online and offline learning time, and establish online and offline course learning tasks in advance according to the course content [7]. This process still requires more teachers to invest a lot of energy, complete the various teaching links efficiently, accumulate corresponding teaching experience, exchange and share in the teaching and discussion activities, and promote the integration of online open curriculum construction and traditional classroom teaching practice.

\subsection{Reform Various Assessment Methods for Online Open Courses and Open Credit Certification}

With the overall rise of the online open courses construction, in the process of course designing and using, the constructors have paid a lot of efforts to realize the growing prosperity of the online open courses. However, the use of online open courses also involves the reform of the assessment system 
of each teaching unit. The unified closed-book examination applicable to traditional classroom teaching cannot meet the requirements of the current popular mixed online and offline teaching mode. Therefore, the assessment method of online open courses needs more attention and scientific design from practitioners. In the basic principle of process-based and diversity of course assessment, all kinds of data of students' online learning can be collected in time with the help of computer technology in the assessment and reasonable analysis results can be formed. Scientific and comprehensive evaluation can be made on each student's learning process, learning effect, learning ability and learning attitude. In addition, considering that the recognition of the learning effect of online courses is conducive to ensuring the enthusiasm of students in the later stage of online open courses learning, the academic affairs department of the school needs to issue relevant policies in a timely manner and grant credit certification for students' online courses learning and establish an online and offline credit interworking channel to encourage students to learn online courses independently in order to give play to the effectiveness of online open courses.

\section{Conclusion}

The active construction of quality online open courses not only reflects the university's enthusiastic response and reform measures to higher education and talent cultivation requirements in the new era, but also provides a new teaching model and interaction way for teachers and students in universities. In the course construction process, from the teaching department of the school to the front-line teachers, the integration of public aspirations, bold practice, fully explore the methods and strategies of online open courses construction. Since various online open courses have been put into use, the teaching of college undergraduates has presented a more free, open and integrated situation, and the students' learning concepts and teaching methods have produced better teaching results.

\section{Acknowledgement}

This research was financially supported by the Project of Innovation in Postgraduate Education (Project No.: SDYY15037) and the Program of Teaching Reform Program of Qingdao university of science and technology (Project No.: 101/0101050192).

\section{References}

[1] L. Mu, J. Zhang, X.P. Wan. Giving play to the effectiveness of online open courses and promoting the reform of the student-centered teaching model [J]. China University Teaching, 2017, (6): 54-55.

[2] Y.G. Song. To build an online open course service system with the spirit of innovation base on the exploration and practice of "i-course" [J]. China University Teaching, 2018, (1): 12-16.

[3] X.H. Su, T.T. Wang, Y. Zhang, et al. Exploration and practice of the blended teaching mode based on flipped classroom of large class [J]. China University Teaching, 2017, (7): 54-62.

[4] Z. Xie, C.H. Zhang, J.P. Li. Analysis on online learning behaviors of MOOCs for advanced mathematics [J]. College Mathematics, 2018, (34): 41-45.

[5] X.Y. Li, L.L. Tian. Research on strategies for promoting teaching effect of the Micro lesson design in colleges and universities [J]. Journal of Higher Education, 2017, (20): 111-114.

[6] X.M. Li, C.J. Hu. Advantages and disadvantages of online open courses [J]. Contemporary Education Research and Teaching Practice, 2018, (10): 12-15. 
[7] L.G. Sun, L.P. Zhou, S.J. Li. Reform of electrical-engineering mixed classroom teaching mode based on online open courses [J]. Education Forum. 2018, (44): 121-122. 